\title{
BMJ Psychosocial risk factors, job open characteristics and self-reported health in the Paris Military Hospital Group (PMHG): a cross-sectional study
}

\author{
Jean-François Ferrand, ${ }^{1}$ Catherine Verret, ${ }^{2}$ Julie Trichereau, ${ }^{2}$ \\ Jean-Philippe Rondier, ${ }^{3}$ Patrice Viance, ${ }^{4}$ René Migliani ${ }^{2}$
}

To cite: Ferrand J-F, Verret C, Trichereau J, et al. Psychosocial risk factors, job characteristics and self-reported health in the Paris Military Hospital Group (PMHG): a cross-sectional study. BMJ Open 2012;2: e000999. doi:10.1136/ bmjopen-2012-000999

- Prepublication history for this paper is available online. To view these files please visit the journal online (http:// dx.doi.org/10.1136/ bmjopen-2012-000999).

Received 2 March 2012 Accepted 29 June 2012

This final article is available for use under the terms of the Creative Commons Attribution Non-Commercial 2.0 Licence; see http://bmjopen.bmj.com

${ }^{1} \mathrm{HIA}$ Bégin, Centre de Médecine de Prévention des Armées, Saint-Mandé, France ${ }^{2}$ Centre d'Epidémiologie et de Santé Publique des Armées, HIA Bégin, Saint-Mandé, France

${ }^{3}$ Département de Psychiatrie, HIA Percy, Clamart, France

${ }^{4}$ Direction Centrale du

Service de Santé des Armées, Vincennes, France

Correspondence to Dr Jean-François Ferrand; ferrand.jeff@wanadoo.fr

\section{ABSTRACT}

Objectives: To investigate the associations between psychosocial risk factors and self-reported health, taking into account other occupational risk factors.

Design: Cross-sectional survey using a self-administered questionnaire.

Setting: The three military hospitals in Paris, France. Participants: Surveys were distributed to 3173 employees (1807 military and 1336 civilian), a total of 1728 employees completed surveys. Missing data prohibited the use of 26 surveys.

Primary and secondary outcome measures: The authors used Karasek's model in order to identify psychosocial factors (psychological demands, decisional latitude, social support) in the workplace. The health indicator studied was self-reported health. Adjustments were made for covariates: age, gender, civil or military status, work injury, ergonomic score, physical and chemical exposures, and occupational profile. Occupational profile was defined by professional category, department, work schedule, supervisor status and service-related length in the hospital.

Results: Job strain (defined as high psychological demands and low decisional latitude) (adjusted $\mathrm{OR}$ $2.1,95 \% \mathrm{Cl} 1.5$ to $2.8, \mathrm{p}<0.001$ ) and iso-strain (job strain with low social support) were significantly associated with moderate or poor self-reported health. Among covariates, occupational profile $(p<0.001)$ and an unsatisfactory ergonomic score (adjusted OR 2.3 95\% Cl 1.6 to $3.2, \mathrm{p}<0.001$ ) were also significantly associated with moderate or poor self-reported health.

Conclusions: The results support findings linking moderate or poor self-reported health to psychosocial risk factors. The results of this study suggest that workplace interventions that aim to reduce exposure to psychological demands as well as to increase decisional latitude and social support could help improve self-reported health.

\section{ARTICLE SUMMARY}

Article focus

- Health professionals reported frequently distress at work due to work overloads and the constant confrontation with illness.

- We wanted to investigate the associations between psychosocial risk factors and selfreported health in a military hospital group.

Key messages

- Job strain and iso-strain were found to be associated with poor self-reported health.

- Self-reported health is a unique indication that succeeds in estimating the multidimensional nature of health. It is a relevant synthetic indicator of actual health status.

Strengths and limitations of this study

- One of the strong points is that this study simultaneously explore psychosocial risk factors and occupational risk factors.

- The nature of the studied population and different response rates between civilian and military staff limit the generalisation of the results to healthcare workers in non-military settings.

\section{INTRODUCTION}

Various types of occupational exposure are known to be risk factors for health. Changes in the working environment over the past few decades have led to new risks for workers. These emerging risks come under the heading of psychosocial risks. ${ }^{1}$ They are the 'aspects of the conception, organisation and management of the work, and of the social and environmental settings that have the potential to cause psychological, social or physical damage'. According to Cox and colleagues, psychosocial risks are decisive factors in tension, distress and weariness, leading to stress. ${ }^{2}$ In 2002, Europe made this theme one of its priorities for action, and an outline agreement on the prevention of workplace stress was signed on 8 October 
$2004 .{ }^{3}$ This agreement provided a consensus definition of the state of stress, defined as 'an imbalance between the perceptions that a subject entertains concerning constraints imposed on him or her by his/her environment, and the perception that the person has of his or her own resources to meet these demands' ${ }^{3}$

The 'job strain' model developed by Karasek in the Job Content Questionnaire (JCQ $)^{4}$ is a theoretical model that is well suited to this definition of stress and one of the most widely used model for identifying psychosocial risk factors. According to this model, the deleterious effects of work are due to a combination of high workload demands and low job decisional latitude (job strain). Recently, a moderator of the effects of demand and control, 'social support', was introduced into this model. ${ }^{5}$

Healthcare professionals confront illness and death as part of their occupation, and therefore, they may be at greater risk for stress-related illness. ${ }^{6-8}$ In addition, over the past 10 years, the healthcare sector has undergone considerable restructuring and downsizing aimed at reducing healthcare costs. These changes have led to work overloads. ${ }^{9}$ The French military hospitals, spared these trends so far, are now subject to the same requirements as those in force in civilian hospital facilities. The French military hospitals have roughly as many civilian staff as military staff, answerable to the same requirements for health and safety set out in the labour code. The military hospital contingent is distinct from the civilian contingent by way of certain specific constraints, particularly linked to frequent missions due to current operations in Afghanistan. The aim of the present study was to assess the impact of psychosocial risk factors on the selfreported health of staff, taking into account other occupational exposures.

\section{METHODS}

\section{Population}

The target population of this study was made up of staff from the Paris Military Hospital Group (PMHG). The PMHG consists of Bégin hospital in Saint-Mandé, Percy hospital in Clamart (both Paris suburbs) and Val de Grâce hospital in Paris. Total staff included 1807 military staff and 1366 civilian staff in 1 January 2009, with 2108 being female staff and 1065 male staff.

\section{Study design}

It was an exhaustive cross-sectional study, based on an anonymous self-administered questionnaire. It was circulated by mail delivery to all PMHG staff, with each department receiving a set of questionnaires sufficient for its staff numbers. Each questionnaire was in its own closed envelope, accompanied by a letter explaining the study and a return envelope pre-addressed to the 'Centre d'Epidémiologie et de Santé Publique des Armées' (CESPAMilitary Epidemiology and Public Health Center). Between 3 February 2010 and 1 March 2010, 3173 questionnaires were distributed across the three hospitals. The closing date for return of the questionnaires was set for 30 April 2010. Questionnaires were returned to CESPA by mail delivery. The results of this survey are presented for the three hospitals conjointly.

Instrument and study variables

Self-administered questionnaire:

The part of the self-administered questionnaire established by the authors had six sections: demographic, work, ergonomics, occupational exposures, work accident or injury and self-reported health.

-Demographic included socio-demographic data of age, gender, marital status and civilian or military status.

-Work-related information included: how long the person had worked in the facility, their professional category, the name of the department where they worked, a listing of their working schedules (night or day shift, weekend work, total work hours per week). Professional categories were medical doctor, specialised nurse, nurse, nursing assistant, medicotechnical staff, technical staff and administrative staff.

-The ergonomics section was composed of 12 questions, using a 3-point scale with three options, 'not applicable', 'satisfied' and 'dissatisfied'. The questions included how satisfactory their work area was to them in terms of accessibility, comfort, height of the working surface, ease of handling their equipment, provision and accessibility of required materials, noise levels, thermal comfort, lighting, working schedules, movements on foot and absence of situations exposing to physical or verbal aggression. A total ergonomics score was defined as the sum of these 12 items. Each 'not applicable' was scored 0 , 'dissatisfied' was scored -1 and 'satisfied' was scored 1. A subject was considered dissatisfied with his or her environment if his or her overall score was negative, middle group (neither satisfied nor dissatisfied) if the overall score was null and satisfied if the overall score was positive.

-Two questions enabled the staff to give their feelings on their exposure to ionising radiations and to chemical substances or preparations categorised as 'CMR' (Carcinogens, Mutagens and Reproductive toxins) at the European level and under the French Employment Code. The answer options were 'always', 'often', 'sometimes' and 'never'.

-The total number of new work injuries or accidents within the previous 12 months and the total duration of any sick leave related to these work injuries or accident were also recorded.

-For the assessment of state of health, we opted for the question and response scale that is used by most countries in the Organisation for Economic Co-operation and Development (OECD) for surveys on the health status of their populations: how do you view your state of health? The Likert scale comprised the following response choices: 'very poor', 'poor', 'moderate', 'good' and 'very good'. ${ }^{10}$ For the analyses, perceived health status was recoded as 'good' for responses 'good' and 'very good' and recoded 'moderate or poor' for the other three response options. 
The second part of the self-administered questionnaire collected data on staff experiences of their work and their relationships with their professional environment. It used the JCQ elaborated by Karasek ${ }^{4}$ in order to identify psychosocial risk factors in the workplace. Three dimensions are explored by this instrument:

-The intensity of psychological demands, which is defined as including workload, intensity and fragmentation of the tasks as perceived by the staff

-Decisional latitude, which includes the subjects' perceptions of their own room for control in their decisions concerning work and their scope for using and developing their skills and competence

-Social support in the workplace, which is the assistance that the subject can obtain from his or her superiors or colleagues.

The JCQ questionnaire used in this survey was the validated French version comprising 26 questions. ${ }^{11}$ The responses to the different items are scored from 1 to 4 . Scores for decisional latitude, psychological demands and social support were computed according to the algorithms recommended by Karasek. ${ }^{4}$ For each dimension, when a value was missing, it was replaced with the mean of the other responses obtained for this subject, as recommended by Bosma et $a l^{12}$ If more than one response was missing in the dimension considered, the score was not calculated and that individuals scores were dropped from the analysis. High and low levels of psychological demands, decisional latitude and social support were determined by a cut-off point that corresponded to the medians observed in the sample according to the recommendations by Karasek. ${ }^{4}$ We used the quadrant method explained in the JCQ user's guide to classify job strain and iso-strain exposure. ${ }^{4}$ Job strain was defined by a score greater than the median for psychological demands and a score below the median on decisional latitude. Three other situations were defined: active jobs (high levels of psychological demand and high levels of decisional latitude), passive jobs (low psychological demand and low decisional latitude) and low-strain jobs (low psychological demand and high decisional latitude). Iso-strain was defined by job strain associated with a score below the median for social support.

\section{Statistical analysis}

For quantitative variables, distributions are given in means, SD and ranges. For qualitative variables, results are given in percentages. The comparison of means was performed using Student's tests, and percentages were compared using $\chi^{2}$ tests.

According to military status, gender and professional category, the sample was compared with data from human resources departments of the three hospitals using $\chi^{2}$ tests.

Work-related information (years in the facility, professional category, department, working schedules) was synthesised in the form of an occupational profile. In order to construct the hierarchical variable, 'occupational profile' multiple correspondence analysis (MCA) was used, followed by classification. MCA is a method of data analysis that is suited to tables in which individuals and qualitative variables are crossed. It enables the original variables to be replaced by new synthetic variables (factors). The principle is that it sums up information concerning the factors by decreasing the number of variables. The objective of the classification is to group individuals that are close to one another on the basis of factors retained in the MCA. This yields a hierarchical tree representing the groupings obtained. The groups obtained are then described according to the characteristics of the individuals they comprise.

Self-reported health defined by moderate or poor versus good was considered as a dependant variable and socio-demographic characteristics, occupational profile, ergonomic score, occupational exposures, work accident or injury and job strain were considered as independent variables. We hypothesised that psychosocial risk factors were risk factors for moderate or poor self-reported health after adjustment for other variables.

The ORs and 95\% CIs were estimated using univariable and multivariable analyses of the determinants of moderate or poor self-reported health. The multivariable analyses were performed using stepwise descending logistic regression, including the explicative variables associated with the variable to be explained in univariable analysis with a significance level below $20 \%$. The final model retained only variables significatively associated with the dependant variable $(p<0.05)$. All the presented results were adjusted for hospital. All interactions were tested. Model fit was ascertained using the Hosmer and Lemeshow test.

The descriptive statistical analyses and the logistic regressions were performed using STATA V.9® software (Statacorp) and SPAD ${ }^{\circledR}$ software for the MCA.

\section{RESULTS}

\section{Response rates}

In all, 3173 questionnaires were distributed to the staff, with 1728 returned (response rate 54\%). Twenty-six could not be used due to missing data.

Compared with overall population, respondents were more often military personnel $(62.3 \%$ vs $56.9 \%$ in the PMHG), specialised nurse and medicotechnical staff, and less often technicians (table 1).

\section{Socio-demographic characteristics}

The respondent sample comprised 1095 women (64.3\%) and 525 men $(30.1 \%)$. The mean age of participating subjects was 37 years $(\mathrm{SD}=10.1$, range $18-65)$. There was a significant effect for gender, $\mathrm{t}(1562)=-5.08$, $\mathrm{p}<0.0001$, with male participants being older (mean $=39$ years, $\mathrm{SD}=9.6$ ) than female participants $($ mean $=36.3$ years, $\mathrm{SD}=10.2) \quad($ table 2$)$.

\section{Work characteristics}

\section{Working conditions}

The time already spent working in the facility was 8.4 years on average $(\mathrm{SD}=8.2$, range $1-43, \mathrm{~N}=1591)$ (table 2). 


\begin{tabular}{|c|c|c|c|c|}
\hline & Overall, n (\%) & Respondents, n (\%) & $\chi^{2}$ & p Value \\
\hline \multicolumn{5}{|l|}{ Military status } \\
\hline Civilian & $1366(43.1)$ & $637(37.7)$ & 19.97 & $<0.001$ \\
\hline Military & 1807 (56.9) & 1054 (62.3) & & \\
\hline \multicolumn{5}{|l|}{ Gender } \\
\hline Female & $2108(66.4)$ & $1095(67.6)$ & 0.97 & 0.32 \\
\hline Male & 1065 (33.6) & $525(32.4)$ & & \\
\hline \multicolumn{5}{|l|}{ Professional category } \\
\hline Medical doctor & $489(15.4)$ & $211(13.3)$ & 83.77 & $<0.001$ \\
\hline Nurse & $668(21.1)$ & $355(22.3)$ & & \\
\hline Specialised nurse & $149(4.7)$ & $110(6.9)$ & & \\
\hline Medicotechnician & $249(7.8)$ & 195 (12.3) & & \\
\hline Technician & $540(17.0)$ & 206 (13.0) & & \\
\hline Administrative & 609 (19.2) & 315 (19.8) & & \\
\hline Nursing assistant & $469(14.8)$ & $198(12.4)$ & & \\
\hline
\end{tabular}

The majority of the staff were liable to work weekends $(\mathrm{N}=1163,69.1 \%)$ or nights $(\mathrm{N}=889,53.2 \%)$. The relation between weekend work and military status was significant, $\chi^{2} \quad(1, \quad \mathrm{~N}=1677)=312.3, \quad \mathrm{p}<0.001$. The proportion of all military staff working weekends was larger than that for all the civilian staff $(84.4 \%$ vs $43.1 \%)$.

Numerous respondents reported regularly working extra hours without compensation ( $\mathrm{N}=757,45.5 \%)$.

Among the respondents, 574 reported having positions involving supervising others. There was a significant effect for gender, $\chi^{2}(1, \mathrm{~N}=1516)=49.6, \mathrm{p}<0.001$, $48.4 \%$ of all the men had these functions and only $29.9 \%$ of all women. There was also a significant effect for military status, $\chi^{2}(1, \mathrm{~N}=1583)=74.7, \mathrm{p}<0.001,44.2 \%$ of all military staff had supervisor status versus $22.6 \%$ for all civilian staff.

The distribution of respondents according to professional category is presented in table 1 . The most common professional category was non-specialised nursing personnel $(\mathrm{N}=355,22.3 \%)$.

Among departments, medical specialities $(\mathrm{N}=488)$, emergency services, intensive care $(\mathrm{N}=240,15.9 \%)$ and surgical specialities $(\mathrm{N}=230,15.2 \%)$ accounted for around $60 \%$ of the subsample.

From these variables relating to work characteristics, MCA enabled classification of 1411 staff across the six following occupational profiles: administrative $(\mathrm{N}=289$ : administrative staff, no weekend or night work, no supervisory function), technician $(\mathrm{N}=161$ : technicians, generally no weekend or night work, no extra hours, mean time in the facility more than 12 years, no supervisory function), medical technician ( $\mathrm{N}=183$ : medical technicians in radiology, pharmacy and laboratories, no weekend or night work, for the majority no supervisory function), specialised nurse ( $\mathrm{N}=105$ : specialised nurses in anaesthesia, intensive care and surgical specialities, work at nights and weekends, frequent extra hours and supervisory functions), medical doctor $(\mathrm{N}=205$ : physicians, pharmacists, dentists, work at weekends, frequent extra hours), nurse and nursing assistant $(\mathrm{N}=468$ : nurses and assistant nurses, work at nights and weekends, mean time in the facility under 6 years). An occupational profile could not be defined for 291 subjects on account of missing data.

\section{Ergonomic characteristics and occupational exposure}

The highest satisfaction rate $(90 \%)$ was obtained for the accessibility of the work post and the lowest rate concerned situations in which physical or verbal aggression occurred, with only $35 \%$ of the staff reporting that they were not subjected to this type of behaviour (table 2). The overall assessment of the ergonomic environment was expressed by the variable ergonomic score. For 321 subjects $(18.9 \%)$, this score was not satisfactory.

More than half of the respondents (55\%) reported exposure to carcinogenic chemical agents, among whom $26 \%$ reported that this was often or always. For ionising radiations, $45 \%$ of the respondents reported exposure, and $18 \%$ reported that this occurred often or always.

\section{Work accident or injury}

In the sample $(\mathrm{N}=1691)$, the proportion of staff reporting at least one working accident in the preceding 12 months was $7.8 \%$. The proportion of accidents leading to sick leave was $3.5 \%$, and the mean duration of sick leave was 24 days $(\mathrm{SD}=35)$, ranging from 1 to 150 days. The proportion of working injury and accidents was significantly different between subjects who were dissatisfied for their ergonomic score $(14.2 \%)$, neither satisfied nor dissatisfied $(11.1 \%)$ and satisfied for their ergonomic score $(5.9 \%) \chi^{2}(2, \mathrm{~N}=1689)=25.7, \mathrm{p}<0.001$.

\section{Description of psychosocial risk factors}

In table 2, results for the score obtained for the three dimensions 'decisional latitude', 'psychological demands' and 'social support' are presented. The median values of these dimension scores enabling 
Table 2 Sample characteristics ( $N=1702, P M H G ~ 2010)$

\begin{tabular}{|c|c|c|}
\hline Characteristics & Mean (SD) & n (\%) \\
\hline \multicolumn{3}{|c|}{ Socio-demographic characteristics } \\
\hline Age (years) & $37(10.1)$ & \\
\hline Gender (female) & & $1095(64.3)$ \\
\hline Marital status & & $1001(60.7)$ \\
\hline Military status & & $1054(62.3)$ \\
\hline \multicolumn{3}{|l|}{ Work characteristics } \\
\hline Years in the facility & $8.4(8.2)$ & \\
\hline Weekend work & & $1163(69.1)$ \\
\hline Night work & & $889(53.2)$ \\
\hline $\begin{array}{l}\text { Overrunning the } \\
\text { schedule }\end{array}$ & & $757(45.5)$ \\
\hline Supervisor status & & $574(36)$ \\
\hline \multicolumn{3}{|l|}{ Department } \\
\hline Medical specialities & & $488(29.6)$ \\
\hline Surgical specialities & & $230(15.2)$ \\
\hline $\begin{array}{l}\text { Emergency, intensive } \\
\text { care }\end{array}$ & & $240(15.9)$ \\
\hline $\begin{array}{l}\text { Laboratories and } \\
\text { pharmacy }\end{array}$ & & $142(9.4)$ \\
\hline Radiology & & $78(5.2)$ \\
\hline $\begin{array}{l}\text { Administrative } \\
\text { department }\end{array}$ & & $373(24.7)$ \\
\hline \multicolumn{3}{|c|}{$\begin{array}{l}\text { Occupational profile (synthesises 'work characteristics', } \\
\text { 'professional category' and 'department') }\end{array}$} \\
\hline Administrative & & $289(20.5)$ \\
\hline Technician & & $161(11.4)$ \\
\hline Medical technician & & $183(13)$ \\
\hline Specialised nurse & & $105(7.5)$ \\
\hline $\begin{array}{l}\text { Nurse and nursing } \\
\text { assistant }\end{array}$ & & $468(33.2)$ \\
\hline Medical doctor & & $205(14.4)$ \\
\hline
\end{tabular}

Ergonomic characteristics ('satisfied' respondents for each item)

\begin{tabular}{lr} 
Accessibility & $1452(90)$ \\
Height of the work top & $1270(83)$ \\
Lighting & $1243(75)$ \\
Working hours & $1243(75)$ \\
Noise level & $1226(74)$ \\
Movements on foot & $1086(69)$ \\
Mechanical aids & $762(66)$ \\
Postural comfort & $1071(66)$ \\
Ambient temperature & $1083(65)$ \\
Anticipation of & $944(61)$ \\
material requirements & \\
Handling & $757(55)$ \\
Absence of physical & $555(35)$ \\
or verbal aggression & \\
Ergonomic score & \\
Satisfied & $1268(74.6)$ \\
Middle group & $111(6.5)$ \\
Dissatisfied & $321(18.9)$ \\
Occupational exposures & \\
Carcinogenic chemical agents & \\
$\quad$ Always & \\
Often & \\
Sometimes & \\
Never & $268(16)$ \\
$\quad$ & $437(29)$ \\
& $801(45)$ \\
\hline
\end{tabular}

\begin{tabular}{|c|c|c|}
\hline Characteristics & Mean (SD) & n (\%) \\
\hline \multicolumn{3}{|l|}{ Ionising radiations } \\
\hline Always & & $91(5)$ \\
\hline Often & & $224(13)$ \\
\hline Sometimes & & $452(27)$ \\
\hline Never & & $915(55)$ \\
\hline \multicolumn{3}{|l|}{ Work accident or injury } \\
\hline $\begin{array}{l}\text { Total work injury* } \\
\text { (with sick leave) }\end{array}$ & & $\begin{array}{l}132(7.8) \\
(59(3.5))\end{array}$ \\
\hline $\begin{array}{l}\text { Duration of sick } \\
\text { leave (days) }\end{array}$ & $24(35)$ & \\
\hline \multicolumn{3}{|c|}{ Psychosocial risk factors (Karasek) } \\
\hline $\begin{array}{l}\text { Decisional latitude } \\
\text { axis score [median] }\end{array}$ & $\begin{array}{l}69.3 \\
(11.1)[70]\end{array}$ & \\
\hline Psychological demands & $24.7(4.7)$ & \\
\hline axis score [median] & [25] & \\
\hline Social support & $23.1(4.2)$ & \\
\hline axis score [median] & [24] & \\
\hline Job strain & & $423(26.1)$ \\
\hline Iso-strain & & $348(21.9)$ \\
\hline \multicolumn{3}{|l|}{ Health indicator } \\
\hline $\begin{array}{l}\text { Moderate or poor } \\
\text { self-reported health }\end{array}$ & & $525(31)$ \\
\hline
\end{tabular}

identification of situations of job strain and iso-strain were, respectively, 70, 25 and 24. Among the 1622 subjects for whom the decisional latitude and psychological demand scores were available, 423 (26.1\%) met the definition of job strain. Among the 1593 subjects for whom decisional latitude score, psychological demand and social support scores were available, 348 (21.9\%) met the definition for iso-strain.

In figure 1, showing psychological demands on the abscissa and decisional latitude on the ordinate, sample participants are positioned according to their occupational profile (table 2). Only the profile 'nurse and nursing assistant' appears in the job strain zone. The profile 'specialised nurse' was on the verge of quadrants 'job strain' and 'active jobs'.

\section{Description of health status}

When staff were asked to assess their general state of health, $1 \%(\mathrm{~N}=17)$ considered it was very poor, $3.1 \%$ $(\mathrm{N}=53)$ responded it was poor, $26.9 \% \quad(\mathrm{~N}=455)$ moderate, $53.6 \% \quad(\mathrm{~N}=908)$ good and $15.4 \% \quad(\mathrm{~N}=260)$ very good. After recoding with a two-level variable, perceived health was considered moderate or poor for $31 \%(\mathrm{~N}=525)$ of respondents (table 2). Moderate or poor health status was more often reported among women, civilian staff, in the $40+$ age group, among those with a non-satisfactory ergonomic score and among those who had had at least one working accident in the preceding 12 months. According to the occupational profile, moderate or poor health status was more frequently perceived among technician profile (43\%), and the lowest frequency was among doctors (table 3). 
Figure 1 Means of the scores for decisional latitude and psychological demands according to the occupational profile $(\mathrm{N}=1702$, PMHG 2010).

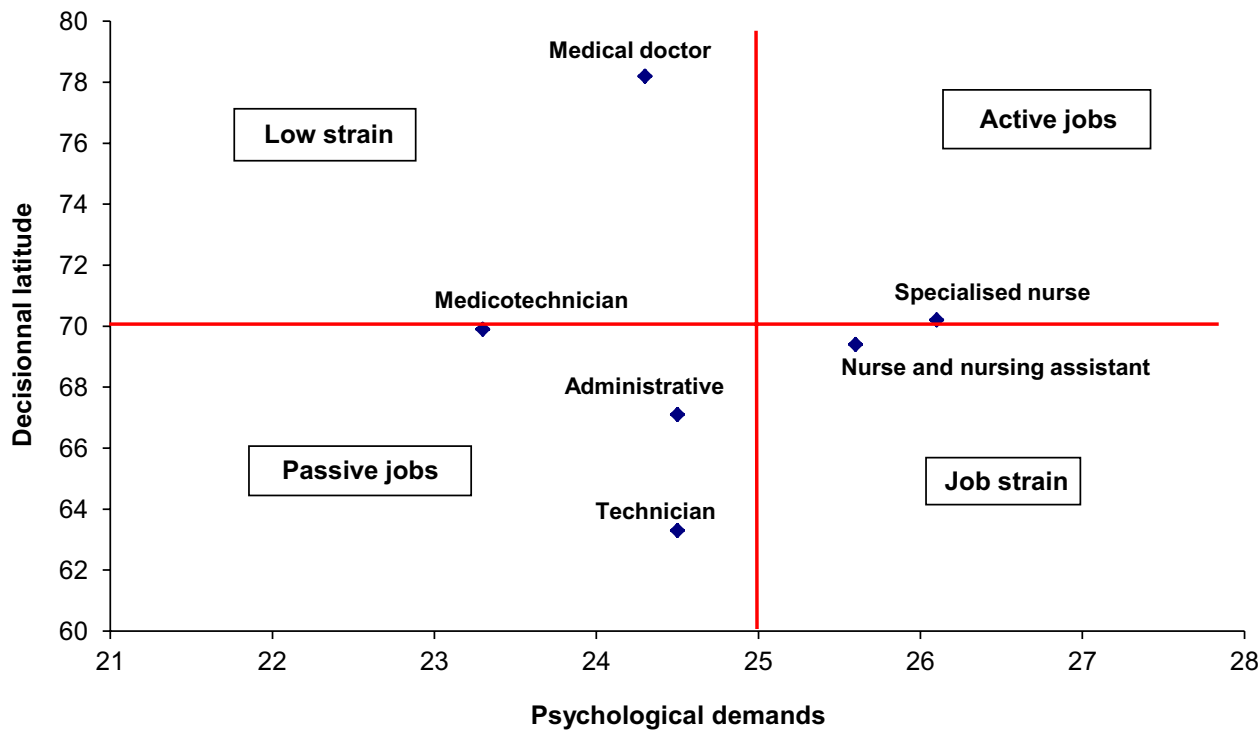

\section{Multivariable analysis}

Table 3 presents variables associated with moderate or poor perceived health in univariable and multivariable analysis. In multivariable analysis, the following variables were significantly associated:

-Military status

-Occupational profile, using doctors as the reference profile-moderate or poor perceived health was significantly more often perceived by the profiles nurse and nursing assistant, technician and administrative

-Ergonomic score

-Work accident or injury

-Job strain

When the variable job strain was replaced in the model by the variable iso-strain, all the variables were significantly associated with the exception of occupational exposures (results not shown).

The final model fitted the data $(\mathrm{p}=0.49)$, and no interaction was found.

\section{DISCUSSION}

In this study on staff in military hospitals in Paris and its urban area, psychosocial risk factors (job strain and isostrain) were found to be associated with moderate or poor perceived health. These associations remained strong even after adjustment on socio-demographic variables and work characteristics (ergonomic score, occupational exposures, occupational profile). Among work characteristics, two variables were associated with moderate or poor perceived health, the ergonomic score and the occupational profile.

The Karasek model used in this study presents several advantages. It is one of the most widely used model in the area of workplace health. ${ }^{13-15}$ In addition, the tool has a French version, and a medical surveillance risk survey in 2003 (SUMER 2003) enabled verification of its psychometric qualities in a French population, thus excluding cultural bias and providing a reference for comparison with other studies. ${ }^{11}$ Finally, several studies have shown the association between situations of job strain or iso-strain and cardiovascular disease ${ }^{16}$ musculoskeletal disorders ${ }^{17}$ and mental illness. ${ }^{18}$ In our sample, the proportion of $26 \%$ of the personnel in a situation of job strain is derived from the definition of job strain on the basis of the medians of the scores for psychological demands and decisional latitude. By construction, it therefore groups around a quarter of the sample studied. Table 4 presents the scores measured in the course of this study and in four other studies. ${ }^{19-22}$ For each of the three dimensions in the Karasek model, means and medians in our sample were very close to those measured in Nantes University Hospital (NUH) in 2005. ${ }^{19}$ In Geneva University Hospital, the score for psychological demands was of the same order of magnitude, the score for social support was a little higher and that for decisional latitude was markedly higher than in the two French studies. ${ }^{20}$ In relation to scores for French salaried workers as a whole, measured in the SUMER 2003 report, ${ }^{21}$ the scores for psychological demands among hospital staff are higher (NUH, Geneva University Hospital, PMHG). Scores from a rubber glove factory in Thailand were lower for social support and for decisional latitude; they are not comparable for psychological demands because a different scale was used. ${ }^{22}$ In our study, nurses and nursing assistants were in job strain situation (figure 1), and this category was similarly classified in the NUH study. There nursing assistants, administrative staff and non-specialised nurses were also found to be undergoing job strain. ${ }^{19}$ In our sample, the specialised nurses appeared to have more decisional latitude, shown by their situation on the verge between 'active job' and 'job strain' situations, while lesser psychological demands placed administrative agents in passive job situations. Compared with French workers in the SUMER 2003 study, the evaluation of psychosocial risk factors in the PMHG confirmed the higher level of psychological demands among hospital staff (table 4).

Concerning the variables descriptive of the workplace, non-typical working hours, night shifts and working over 
Table 3 Factors associated with moderate or poor self-reported health, job strain as an explicative variable (logistic regression, univariable and multivariable analyses ( $N=1200$, PMHG 2010))

\begin{tabular}{|c|c|c|c|c|c|c|}
\hline & \multicolumn{2}{|c|}{ Self-reported health } & & & & \\
\hline & \multirow{2}{*}{$\begin{array}{l}\text { Moderate or } \\
\text { poor }(\mathrm{N}=340) \\
\mathrm{n}(\%)\end{array}$} & \multirow{2}{*}{$\begin{array}{l}\text { Good } \\
(N=860) \\
n(\%) \\
\end{array}$} & \multicolumn{2}{|c|}{ Univariable analysis* } & \multicolumn{2}{|c|}{ Multivariable analysis* } \\
\hline & & & OR $(95 \% \mathrm{Cl})$ & p Value & OR $(95 \% \mathrm{Cl})$ & p Value \\
\hline Gender & & & & 0.002 & & NSt \\
\hline Male & $96(22.9)$ & $323(77.1)$ & 1.0 & & & \\
\hline Female & 244 (31.2) & $537(68.8)$ & 1.5 (1.2 to 2.0$)$ & & & \\
\hline Military status & & & & $<0.001$ & & 0.006 \\
\hline Civilian & $145(37.7)$ & $240(62.3)$ & 1.0 & & 1.0 & \\
\hline Military & 195 (23.9) & $620(76.1)$ & $0.5(0.4$ to 0.7$)$ & & $0.6(0.5$ to 0.9$)$ & \\
\hline Age (years) & & & & 0.03 & & NS \\
\hline$<31$ & $100(23.9)$ & $319(76.1)$ & 0.7 (0.5 to 1.0$)$ & & & \\
\hline $31-40$ & $132(32.0)$ & $280(68.0)$ & $1.1(0.8$ to 1.5$)$ & & & \\
\hline$>40$ & $108(29.3)$ & $261(70.7)$ & 1.0 & & & \\
\hline Occupational profile & & & & $<0.001$ & & $<0.001$ \\
\hline Medical doctor & $20(11.0)$ & $162(89.0)$ & 1.0 & & 1.0 & \\
\hline Technician & $55(43.0)$ & 73 (57.0) & 6.1 (3.4 to 11.0$)$ & & $3.6(1.8$ to 7.9$)$ & \\
\hline Medical technician & $36(23.0)$ & $119(77.0)$ & 2.5 (1.4 to 4.5$)$ & & 1.7 (0.9 to 3.3$)$ & \\
\hline Specialised nurse & $18(19.6)$ & 74 (80.4) & 2.0 (1.0 to 3.9$)$ & & 1.2 (0.6 to 2.6$)$ & \\
\hline $\begin{array}{l}\text { Nurse end nursing } \\
\text { assistant }\end{array}$ & $136(32.4)$ & $284(67.6)$ & 3.9 (2.3 to 6.4$)$ & & 2.6 (1.6 to 4.7$)$ & \\
\hline Administrative & $74(33.2)$ & $149(66.8)$ & 4.0 (2.3 to 6.9$)$ & & 2.8 (1.6 to 5.0$)$ & \\
\hline Occupational exposures & & & & 0.10 & & NS \\
\hline Always & $58(32.8)$ & $119(67.2)$ & 1.4 (1.0 to 2.0$)$ & & & \\
\hline Often & 88 (31.3) & $193(68.7)$ & $1.3(0.9$ to 1.7$)$ & & & \\
\hline Sometimes & $194(26.1)$ & $548(73.9)$ & 1.0 & & & \\
\hline Ergonomic score & & & & $<0.001$ & & $<0.001$ \\
\hline Dissatisfied & $101(46.8)$ & $115(53.2)$ & 2.8 (2.1 to 4.0$)$ & & 2.3 (1.6 to 3.2 ) & \\
\hline Middle & $23(29.5)$ & $55(70.5)$ & $1.3(0.8$ to 2.2$)$ & & $1.1(0.6$ to 1.8$)$ & \\
\hline Satisfied & $216(24.3)$ & $690(75.7)$ & 1.0 & & 1.0 & \\
\hline Work accident or injury $\ddagger$ & & & & $<0.001$ & & 0.03 \\
\hline Yes & $45(45.0)$ & $55(55.0)$ & $2.2(1.5$ to 3.4$)$ & & 1.7 (1.1 to 2.7$)$ & \\
\hline No & $295(26.8)$ & 805 (73.2) & 1.0 & & 1.0 & \\
\hline Job strain & & & & $<0.001$ & & $<0.001$ \\
\hline Yes & $133(43.9)$ & $170(56.1)$ & 2.6 (2.0 to 3.4$)$ & & 2.1 (1.5 to 2.8$)$ & \\
\hline No & $207(23.1)$ & $690(76.9)$ & 1.0 & & 1.0 & \\
\hline
\end{tabular}

hours without compensation were frequently reported (70\% for work at weekends, $53 \%$ for working at night and $45 \%$ for extra hours). In France, in the public hospital sector in 2006, $60 \%$ of the salaried staff were liable to work weekends (PMHG 70\%), 25\% of the staff overall worked nights, among whom $40 \%$ were doctors and nurses (PMHG 53\%), and 31\% reported frequently working over hours (PMHG 45\%). ${ }^{23}$ The larger proportions in our study could be explained by the relative overrepresentation of military staff, medicotechnical agents and specialised nurses (since these categories are the ones that are most often on duty at night and at the weekend). Apart from extra hours, working at night and during the weekend are specific to organisational patterns in hospital environments, and these constraints on social and family life were well accepted by PMHG staff; since in the items relating to the evaluation of ergonomic aspects, $75 \%$ reported that they were satisfied with their working hours.
This acceptation does not, however, protect from possible effects on health. In the short term, the main effects described in the literature are nutritional imbalances and sleep disorders. Longer term effects are subject to more debate, with certain studies concluding to higher rates of morbidity after the age of 40 and a tendency to an increase in ischaemic cardiac or breast cancer risk. ${ }^{24-26}$

In relation to the profile for doctors, our results showed that the probability for a subject to perceive him/herself to have moderate or poor health status was significantly greater for all the other profiles except for the specialised nurses and medical technician. This result is coherent with data in the literature, where it is noted that subjects with lower educational level or lower income level do not have so positive a view of their health as subjects with higher educational or income levels. ${ }^{10}$

Our results also showed a statistical association between a non-satisfactory ergonomic score and 
Table 4 Comparison of Karasek scores for PMHG and several other studies (PMHG 2010)

\begin{tabular}{|c|c|c|c|c|c|}
\hline & \multirow[b]{2}{*}{ No. of items } & \multirow[b]{2}{*}{$\mathbf{N}$} & \multicolumn{3}{|l|}{ Scores } \\
\hline & & & Mean & Median & Possible score \\
\hline \multicolumn{6}{|l|}{ Psychological demand } \\
\hline $\mathrm{PMHG}$ & 9 & 1702 & 24.7 & 25 & $9-36$ \\
\hline Nantes University Hospital & 9 & 1836 & 24.6 & 24.5 & $9-36$ \\
\hline SUMER & 9 & 24486 & 21.7 & 21 & $9-36$ \\
\hline Rubber Glove Factory (Thailand) & 5 & 200 & 33 & & $12-48$ \\
\hline Geneva University Hospital & 9 & 1298 & $23.4\left(53.2^{\star}\right)$ & & $9\left(0^{\star}\right)-36\left(100^{\star}\right)$ \\
\hline \multicolumn{6}{|l|}{ Decisional latitude } \\
\hline PMHG & 9 & 1702 & 69.3 & 70 & $24-96$ \\
\hline Nantes University Hospital & 9 & 1836 & 69.5 & 70 & $24-96$ \\
\hline SUMER & 9 & 24486 & 70 & 70.3 & $24-96$ \\
\hline Rubber Glove Factory (Thailand) & 9 & 200 & 63.7 & & $24-96$ \\
\hline Geneva University Hospital & 9 & 1298 & $72.3\left(67.1^{\star}\right)$ & & $24\left(0^{\star}\right)-96\left(100^{\star}\right)$ \\
\hline \multicolumn{6}{|l|}{ Social support } \\
\hline $\mathrm{PMHG}$ & 8 & 1702 & 23.1 & 24 & $8-32$ \\
\hline Nantes University Hospital & 11 & 1836 & 22.7 & 23 & $8-32$ \\
\hline SUMER & 8 & 24486 & 23 & 23.3 & $8-32$ \\
\hline Rubber Glove Factory (Thailand) & 8 & 200 & 21.9 & & $8-32$ \\
\hline Geneva University Hospital & 8 & 1298 & $23.9\left(66.4^{\star}\right)$ & & $8\left(0^{\star}\right)-32\left(100^{\star}\right)$ \\
\hline
\end{tabular}

moderate or poor perceived health. The questions relating to the ergonomics of the work post enabled identification of unsatisfactory situations (handling, anticipation of material requirements, situations of physical or verbal aggression), and these results are of the same general order of magnitude and coherent with those in the literature relating to working conditions among hospital staff. Concerning handling and carrying, $55 \%$ of the respondents reported that they were satisfied in PMHG, $52 \%$ in NUH, ${ }^{19}$ and in the Presst-Next survey conducted among staff in healthcare environments in France, means for handling of heavy loads were considered satisfactory by $48 \%$ of the staff questioned. ${ }^{27}$ The figures for alleged physical or verbal aggression are striking on account of the scale of the problem, but coherent with data in the report on working conditions in health facilities in 2003, where $71 \%$ of the staff reported that they were exposed to verbal aggression and $54 \%$ reported that they had experienced physical aggression. ${ }^{28}$ These hostile behaviours can have serious repercussions on the psychological well-being of the persons concerned, showing up in particular in posttraumatic stress disorders which can also damage the social atmosphere in the facility. ${ }^{29} 30$

Working accidents can be considered as an indicator of the immediate effects of working conditions. In the SUMER 2003 report, $4.3 \%$ of the workers questioned reported at least one accident at work followed by sick leave in the 12 months preceding the survey (vs $3.5 \%$ in our study). The mean number of notified days off work was 24 (and 24 in the PMHG study likewise). ${ }^{31}$ Thus, the reported accident rate in our sample was below that reported in SUMER 2003. According to the data provided by the French health ministry in its 2008 social overview, for salaried workers as a whole, the mean rate of work accidents is $10.6 \% .^{32}$ In our study, the proportion of work accidents in the previous 12 months (with or without sick leave) was $7.8 \%$. The results of this study also yielded a work accident rate that was below that of civilian hospitals.

For the assessment of state of health, a subject is considered to be in good health by OECD for the responses 'good' and 'very good'. ${ }^{10}$ Although a threelevel variable (poor, moderate and good) would have been more appropriate, this solution was not possible because we did not have enough people in the poor and very poor perceived health groups. Despite its very general nature and the apparent subjectivity of the response provided, perceived health via a single question does appear as a relevant synthetic indicator of actual health status. In addition, the medical literature reports associations between perceived poor health and mortality, ${ }^{33-35}$ current suicidal ideation ${ }^{36}$ and premature retirement for mental disorder, musculoskeletal disorder and cardiovascular disease. ${ }^{37}$ In France, in 2008, $76 \%$ of the population aged 15 years and over were considered to be in good health compared with $69 \%$ in our study. This less favourable perception was in line with similar recent data relating to the perceived health of staff in civilian hospitals. $^{38}$

Potential limitations to this study include the crosssectional nature, so it is not possible to tell whether moderate or poor perceived health was a result of job strain or job strain was a result of moderate or poor perceived health, which precludes identifying causal risk factors for perceived health. However, previous studies comparing cross-sectional and prospective analyses on the same data have provided elements supporting at least to some extent the validity of cross-sectional results. ${ }^{39}{ }^{40}$ Another limitation is the moderate rate of 
participation and the fact that those with either worse or better perceived health may have been more likely to participate in the study, therefore, potentially biasing the results. Also, different response rates between civilian and military staff and between professional categories raise the issue of selection bias. This selection bias may have affected the absolute levels of the variables measured. This is illustrated if we consider the civilian personnel who more frequently did not report good health status but who were somewhat under-represented in the sample, so that caution is required in interpreting the level of association observed for the perceived health status variable, which was significant. Also, a healthy worker effect may have operated, leading to an underestimation of the associations between occupational factors and moderate or poor perceived health.

Overall, this study was the first on this scale in military hospital setting, and the associations evidenced between psychosocial risk factors and perceived health were measured after adjustment on co-variables, in particular occupational risk factors. One of the strong points of the study is that it simultaneously explores psychosocial risk factors and other risk factors as possible determinants of health status. Consequently, this study efficiently integrated variables linked to the job and also enabled the collection of considerable data on the feelings and perceptions of staff in their workplace.

The results have been presented to the staff who, in working groups, gained awareness of possible effects of a certain number of working situations on their health. They were thus able to suggest awareness-raising action, adaptations in the field of ergonomics (for handling, anticipation of material requirements, situations in which aggression occurs) or in the psychosocial field, such as the participation of all staff categories in department meetings for the explicit purpose of improving communication, for more efficient planning of activities and enhanced support from the hierarchy. The discussion of the results thus altered the perspectives of the staff on their working situations, which on account of established routine were not seen as presenting a risk (for instance working nights) and it enabled better compliance of staff with the prevention action that they themselves initiated.

Acknowledgements We are grateful to all participants. We also thank Catherine Besnard for her help in data collection.

Contributors J-FF, the main researcher, was involved in all phases of the study, including study design, literature search, conduct of the study, data analysis and final article write up. CV was involved in the interpretation of data and in the elaboration of the article, she supervised the study and reviewed the manuscript. JT performed statistical analysis and revised critically the paper for important intellectual content. J-PR was involved in the design of the study and in the drafting of the article. PV and RM were involved in study conception and in the acquisition of data, and they revised critically the manuscript for important intellectual content. All the authors gave the final approval of the version to be published.

Funding This research received no specific grant from any funding agency in public, commercial or not-for-profit sectors.

Competing interests None.
Ethics approval This study was approved under the guidelines for epidemiological studies by CESPA and by PMHG Ethics Committee.

Provenance and peer review Not commissioned; externally peer reviewed.

Data sharing statement There are no additional data available.

\section{REFERENCES}

1. How To Tackle Psychosocial Issues And Reduce Work Related Stress. Bilbao: European Agency for Safety and Health at Work, 2002:127. http://osha.europa.eu/en/publications/reports/309 (accessed 15 May 2012).

2. Cox T, Griffiths A, Rial-Gonzales E. Research On Work-Related Stress. Luxembourg: Office for Official Publications of the European Communities, 2000. http://www.eurofound.europa.eu/ewco/studies/ tn1004059s/tn1004059s_8.htm (accessed 2 Jan 2012).

3. Accord Cadre Européen Sur Le Stress Au Travail. 2004. http://tutb. etuc.org/uk/newsevents/files/Accordcadres\%20STRESS (accessed 2 Jan 2012).

4. Karasek R. Job Content Questionnaire and User's Guide. Los Angeles, CA: Department of Industrial and Systems Engineering, University of Southern California, 1985.

5. Sargent LD, Terry DJ. The moderating role of social support in Karasek's job strain model. Work \& Stress 2000;14:245-61.

6. Bourbonnais R, Bisson C, Vinet A, et al. Effectiveness of a participative intervention on psychosocial work factors to prevent mental health problems in a hospital satteing. Occup Environ Med 2006;63:335-42.

7. Estryb-Behar M, Ponsignon H. Travailler à l'Hôpital. Paris: BergerLevrault, 1989.

8. Estryn-Behar M, Kaminski M, Peigne E, et al. Stress at work and mental health status among female hospital workers. Br J Industr Med 1990;47:20-8

9. Bourbonnais R, Bisson C, Malenfant R, et al. Health care restructuring, work environment and health of nurses. Am J Ind Med 2005; 47:54-64.

10. Base de données de l'OCDE sur la santé. http://stats.oecd.org/index. aspx? DataSetCode=HEALTH_STAT\&lang=fr (accessed 2 Jan 2012).

11. Niedhammer I, Chastang JF, Gendrey L, et al. Propriétés psychométriques de la version française des échelles de la demande psychologique, de la latitude décisionnelle et du soutien social du « Job Content Questionnaire » de Karasek: résultants de l'enquête nationale SUMER. Santé Publique 2006;3:413-27.

12. Bosma $\mathrm{H}$, Marmot $\mathrm{MG}$, Hemingway $\mathrm{H}$, et al. Low job control and risk of coronary heart disease in Whitehall II (prospective cohort) study. BMJ 1997;314:558-65.

13. Choi B, Östergren PO, Canivet $\mathrm{C}$, et al. Synergistic interaction effect between job control and social support at work on general psychological distress. Int Arch Occup Environ Health 2011;84:77-89.

14. Huda BZ, Rusli BN, Naing L, et al. Job strain and its associated factors among lecturers in the School of medical Sciences, University Sains Malaysia and Faculty of Medicine, University Kebangsaan Malaysia. Asia Pac J Public Health 2004;16:32-40.

15. Li J, Yang W, Liu P, et al. Psychometric evaluation of the Chinese (mainland) version of Job Content Questionnaire: a study in university hospitals. Ind Health 2004;42:260-7.

16. Collins SM, Karasek RA, Costas K. Job strain and automatic indices of cardiovascular disease risk. Am J Ind Med 2005;48:182-93.

17. Hannan LM, Monteilh CP, Gerr F, et al. Job strain and risk of musculoskeletal symptoms among a prospective cohort of occupational computer users. Scan J Work Environ Health 2005;31:375-86.

18. Niedhammer I, Chastang JF, David S, et al. Psychosocial work environment and mental Health: job-strain and effort-reward imbalance models in a context of major organizational changes. Int $J$ Occup Environ Health 2006;12:111-19.

19. Tripodi D, Keriven-Dessomme B, Lombrail P, et al. Evaluation des risques professionnels perçus chez le personnel du centre hospitalouniversitaire de Nantes. Archives des maladies professionnelles et de l'environnement 2007:68:457-73.

20. Courvoisier DS, Genevay S, Cedraschi C, et al. Job Strain, Work Characteristics And Back Pain: A Study In A University Hospital. Eur J Pain 2011:15:634-40.

21. Guignon N, Niedhammer I, Sandret N. Les facteurs psycho-sociaux au travail, une évaluation par le questionnaire de Karasek dans l'enquête SUMER 2003. Documents pour le médecin du travail 2008; $115: 389-98$.

22. Sein MM, Howteerakul N, Suwannapong N, et al. Job strain among rubber-glove-factory workers in Central Thailand. Ind Health 2010;48:503-10.

23. Cordier M, Larmat A. Les conditions de travail des personnels du secteur hospitalier public et de la fonction publique de l'état en 2006. 
In: France. Ministère du budget, des comptes publics, de la fonction publique et de la réforme de l'état. Rapport annuel sur l'état de la fonction publique, vol. 1, faits et chiffres 2008-2009. Paris: La documentation française; 2009:227-49. http://www.ladocumentation française.fr/rapports-publics/094000490/index.shtml (accessed 19 Jul 2012).

24. Knauth P. Les horaires de travail. In: Encyclopédie de sécurité et de santé au travail, vol. 2. 3e édn. Genève: BIT, 2000:43-16. 43-2 à.

25. Knutsson A, Hallquist J, Reuterwall C, et al. Shiftwork and myocardial infarction: a case-control study. Occup Environ Med 1999;56:46-50.

26. Schernhammer ES, Kroenke $\mathrm{CH}$, Laden F, et al. Night work and risk of breast cancer. Epidemiology 2006;17:108-11.

27. Estryn-Behar M, Le Nezet O, Duville N. Santé et Satisfaction des Soignants au Travail en Europe. Prévention des Départs Prématurés de la Profession. Brochure 2005: Résultats de l'enquête Presst-Next. http://www.presst-next.fr (accessed 2 Jan 2012).

28. Le Lan R, Bates D, Bauer P, et al. Conditions de travail et relations avec le public dans les établissements de santé en 2003. Dossiers solidarité et santé. Hors série. 2007. http://www.sante.gouv.fr/ les-conditions-de-travail-dans-les-etablissements-de-sante.html (accessed 2 Jan 2012).

29. Chapoutier A. Prise en charge au titre du risque professionnel des troubles psychologiques des salariés victimes d'agression. Travail et sécurité 2003;627:12-13.

30. Felton JS. Violence prevention at the health care site. Occup Med 1997;12:701-15.

31. Hamon-Cholet S, Sandret N. Accidents et Conditions de Travail. Premières Informations Et Premières Synthèses DARES. Paris: La documentation française; 2007; ${ }^{\circ} 31.2$. http://travail-emploi.gouv.fr/ etudes-recherche-statistiques-de,76/etudes-et-recherche,77/ publications-dares,98/dares-analyses-dares-indicateurs, 102/2007-312-accidents-et-conditions,5877.html (accessed 19 Jul 2012).

32. Direction générale de l'offre de soins. Synthèse annuelle des données sociales hospitalières des établissements publics de santé en 2008. Paris: Ministère de la santé; 2008. http://www.sante.gouv.fr/ donnees-sociales-hospitalieres-2008.html (accessed 19 Jul 2012).

33. DeSalvo KB, Fan VS, McDonell MB, et al. Predicting mortality and healthcare utilization with a single question. Health Serv Res 2005;40:1234

34. Miilunpalo S, Vuori I, Oja P, et al. Self-rated health status as a health measure: the predictive value of self-reported health status on the use of physician services and on mortality in the working age population. J Clin Epidemiol 1997;50:517-28.

35. Kawada T. Self-rated health and life prognosis. Arch Med Res 2003:34:343-7.

36. Goodwin R, Olfson M. Self-perception of poor health and suicidal ideation in medical patients. Psychol Med 2002;32:1293-9.

37. Karpansalo M, Manninen P, Kauhanen J, et al. Perceived health as a predictor of early retirement. Scan J Work Environ Health 2004;30:287-92.

38. Estryn-Behar M, Ben-Brik E, Le Nezet O, et al. La situation des soignants des établissements publics et privés en France en 2002. Analyse des résultats de la première partie de l'étude PRESSTNEXT. Archives des Maladies Professionnelles et de l'Environnement 2004;65:413-37.

39. Niedhammer I, Chea M. Psychosocial factors at work and self reported health: comparative results of cross sectional and prospective analyses of the french GAZEL cohort. Occup Environ Med 2003;60:509-15.

40. Theorell T, Hasselhorn HM. On cross-sectional questionnaire studies of relationships between psychosocial conditions at work and health-are they reliable? Int Arch Occup Environ Health 2005;78:517-22. 